\title{
A Review on the Impact of Silver Nanoparticles on Soil Microorganisms and Bioremediation as Heavy Metal Removal Technology
}

\author{
Hartati Oktarina $^{1 *}$, Teuku Mukhriza ${ }^{2}$ \\ ${ }^{1}$ Department of Plant Protection, Universitas Syiah Kuala. Banda Aceh. 23111 \\ ${ }^{2}$ Department of Chemical Engineering, Universitas Syiah Kuala. Banda Aceh. 23111 \\ *Koresponden email: oktarina.hartati@unsyiah.ac.id
}

Received: March 12, 2021

Accepted: 1 April 2021

\begin{abstract}
The increasing and varied use of silver nanoparticles (AgNPs) as antimicrobial on consumer products increases the risk of the nanomaterial release into the environment and potentially harm beneficial microorganisms in soil. Any change in soil microbial composition will lead to soil quality degradation that eventually reduce crop productivity. The negative effect of AgNPs on soil microorganism has been reported by researchers. There are technologies employed to remove heavy metals from soil such as chemical, physical, and biological technique. However, chemical and physical techniques have some disadvantages e.g high cost and partial removal. Therefore, biological technique including the use of microorganisms (bioremediation) become more favourable. The technique is considered as cost effectiveness and environmentally sustainable method. The present paper summarizes the impact of AgNPs on soil microorganisms and the use of microorganisms (bacteria, fungi, algae, and yeast) to eliminate heavy metals pollution in soil.
\end{abstract}

Keywords: AgNPs, algae, bacteria, fungi, yeast

\begin{abstract}
Abstrak
Peningkatan dan variasi penggunaan nano partikel perak (AgNPs) sebagai anti mikroba pada produk konsumen meningkatkan risiko pelepasan nanomaterial tersebut ke lingkungan dan berpotensi membahayakan mikroorganisme non target di dalam tanah. Mikroba tanah memiliki peranan penting sehingga perubahan komposisinya akan berdampak pada kualitas tanah dan pada akhirnya mempengaruhi produktivitas tanaman yang ditanam. Para peneliti telah melaporkan dampak negatif NPAg terhadap mikroorganisme tanah. Teknik penghilangan logam berat pada tanah terkontaminasi biasanya dilakukan secara kimiawi maupun fisik. Namun kedua teknologi ini dinilai tidak efektif dan efisien. Penghilangan logam berat secara biologi telah terbukti lebih efektif, efisien, serta ramah lingkungan. Dalam artikel ini diringkaskan dampak negatif NPAg terhadap mikroorganisme tanah serta potensi mikroorganisme seperti bakteri, fungi, alga, dan kapang untuk mengurangi logam berat pada tanah yang terkontaminasi.
\end{abstract}

Kata kunci : alga, bakteri, fungi, kapang, NPAg

\section{Introduction}

Nanoparticles are particles with size between 1 and 100 nanometres $(1.0 \mathrm{~nm}=10 \mathrm{~m})$. Nanoparticles can be made from a variety of compounds and can be made of metal such as gold ( $\mathrm{Au}$ ), silver (Ag), and silica $(\mathrm{Si})$ or can be made of carbon such as carbon nanotubes that used for water and oil purification [1]. Nowadays, research on nanoparticles are intense due to a wide range of applications in many fields. Different types of nanomaterials are employed to fulfil the purposes of each industry.

Silver nanoparticles (AgNPs) are of particular interest as they have known antimicrobial activity and have a wide range of suggested uses such as in medicine [2] and in agri-food sector [3]. AgNPs are also applied in everyday products such as bed sheets, socks, toothpaste, and towels [4]. The increasing and varied use of AgNPs as antimicrobial on consumer products increases the risk of the nanomaterial release into the environment and potentially harm beneficial microorganisms in soil. Any decreasing in soil microbial composition will lead to soil quality degradation and eventually reduce crop productivity. [5] Reported that AgNPs on fabric can be released into the environment by washing process. In several countries such as Germany, The UK, Spain, France, and Portugal, dry sewage sludge from wastewater treatment is produced as a fertilizer in agricultural and applied on farmland. The sewage sludge still contains Ag because water treatment facilities were not completely removed [6]. In addition, there is also intentional release of 
silver nanoparticles (AgNPs) into the environment. AgNPs applied as fungicides [7] and soil remediation [8] are examples of intentional release of AgNPs into the environment.

The impact of AgNPs on soil microorganisms and soil microbial communities have been reported [9] [10] [11] [12]. Some of variables such as concentration, exposure time, and soil texture may affect the abundance of microbial communities in soils [13] [14] [15] [16]. Furthermore, the properties of AgNPs can be modified that change AgNPs stability, availability, and toxicity to organisms in the soil [17] [18] [19] [20] [21]. [22] Reported that many soil properties such as grain size distribution, heterogeneity and the presence of organic affect the fate of AgNPs in soil. AgNPs transformation including physical, chemical, as well as biological transformations that ultimately affect their persistence, bioavailability/bio-uptake, reactivity, and toxicity in the environment [23]. [24] Revealed that the antibacterial activity of AgNPs depends on their size. The smaller size AgNPs shows more toxicity than larger sized particles, where AgNPs has been released much $\mathrm{Ag}(+)$ ions that dominate antibacterial activity. [25] Found that the surface charge of the AgNPs can affect the bactericidal activity of both gram-positive and gram-negative bacteria. They claimed that surface charge is one of the most important factors that need to be considered in evaluating the toxicity of AgNPs into the environment.

The efforts have been made to overcome soil contaminated problems including the use of chemical, physical, and biological methods. Biological approach (bioremediation) has proven to be more efficient and effective [26]. Bioremediation is a process that primarily uses microbial or plant enzymes to reduce the toxicity level of heavy metal as pollutant [27]. Due to this reason, the present paper summarizes the impact of AgNPs on soil microorganisms and the potential of microorganisms (bacteria, fungi, algae, and yeast) to remove heavy metals contamination.

\section{Material and Methods}

This paper mainly introduce the application of silver nanoparticles as antimicrobial agent on consumer products. The review will examine the effect of AgNPs on beneficial soil microorganisms. Bioremediation as one of the technique to remediate heavy metal in the soil including the mechanism and the challenge are summarized. Finally, the use of microorganisms including bacteria, fungi, algae, and yeast will also be assessed.

\section{Discussion}

\section{Effect of AgNPs on Soil Microorganisms}

Soil microbes play important roles in maintaining soil fertility by fixating nitrogen, degrading organic matter and enhancing the availability of nutrient to the plants [28]. Any reduction in soil microbial composition results in low soil quality and plant productivity. Kumar et al. [29] reported that plantassociated bacteria, Bradyrhizobium canariense, were highly susceptible to AgNPs. It is generally known that $B$. canariense fixes nitrogen to nitrate so that plants can use it to make protein for their growth. It is true that $B$. canariense is not the only nitrogen fixing bacteria while other bacteria might be able to take their place but AgNPs might also affect those bacteria and other beneficial soil microorganisms and reduce the number of species in the environment. A similar observation was made by Calder et al. [11] during their research on the antimicrobial effect of AgNPs towards beneficial soil bacterium, Pseudomonas chlororaphis. A study shows that at environmentally relevant concentrations, AgNPs cause toxic effects on soil microorganisms of the terrestrial ecosystem and changes the diversity [6].

Many studies have reported the effects of AgNPs on microbial communities. For example, reductions in the number of ectomycorrhizal fungal species found on pine roots [12], a decrease in the abundance of nitrifying bacteria in activated sludge [30] and a change in bacterioplankton communities in natural waters [31] have been observed. Recently, [16] claimed that long term exposure of AgNPs changes soil fungal community in soil. Any change in the community composition might affect ecosystem processes. For instance, a change in the soil community will affect plant decomposition processes and nutrient cycling and finally soil quality.

The exact anti-microbial mechanism of AgNPs is still not fully understood. However, studies suggested nanoparticles exert their toxic effects through a variety of mechanisms. For instance, they may stick to cell surfaces [32], penetrate the cells [33], change cell membrane properties and finally result in DNA damage due to the dissolution of Ag ions from the particulate AgNPs [34]. Liao et al. [35] observed the morphology change on P. aeruginosa treated with AgNPs (Fig. 1). They claimed that the antibacterial mechanisms involve imbalance antioxidation and oxidation processes also the failure to remove the excessive reactive oxygen species (ROS). Similarly, [36] noticed morphological change toward Rhizoctonia 
solani colony when exposed to AgNPs (Fig. 2). Antibacterial mechanism of AgNPs is presented diagrammatically on Fig. 3 .
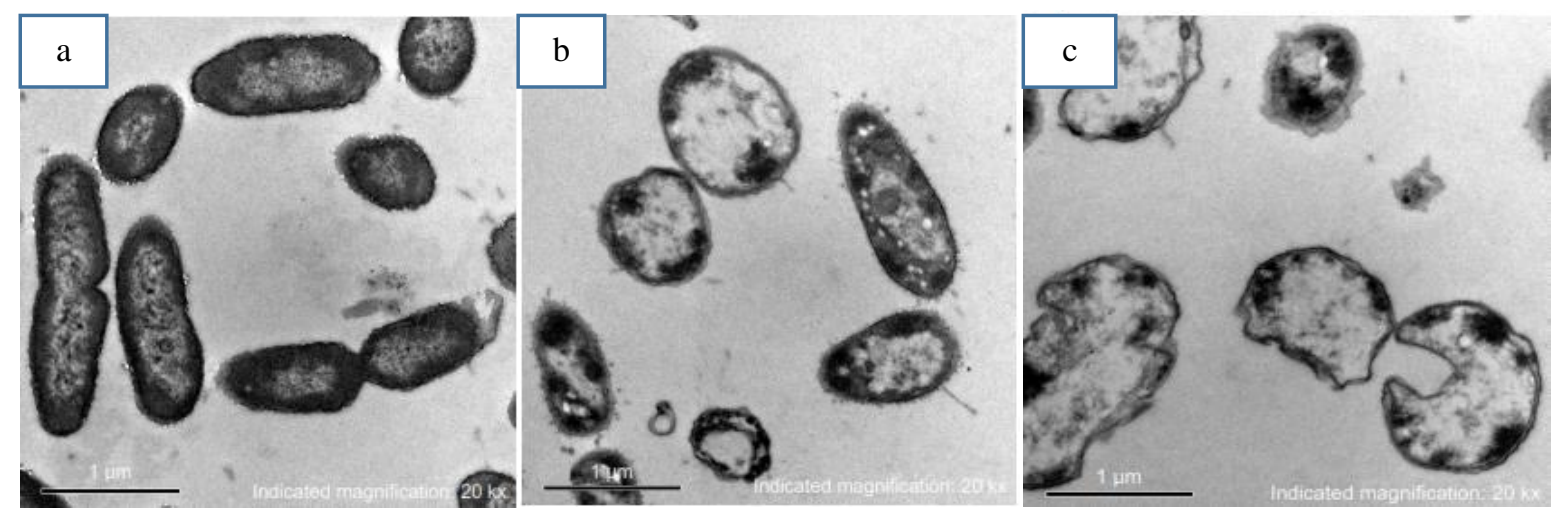

Figure 1. The effect of AgNPs on the morphology and structure Pseudomonas aeruginosa

(a) P. aeruginosa without AgNPs treatment; (b) P. aeruginosa at the early stage of AgNPs treatment;

(c) $P$. aeruginosa at the late stage of AgNPs treatment [35]

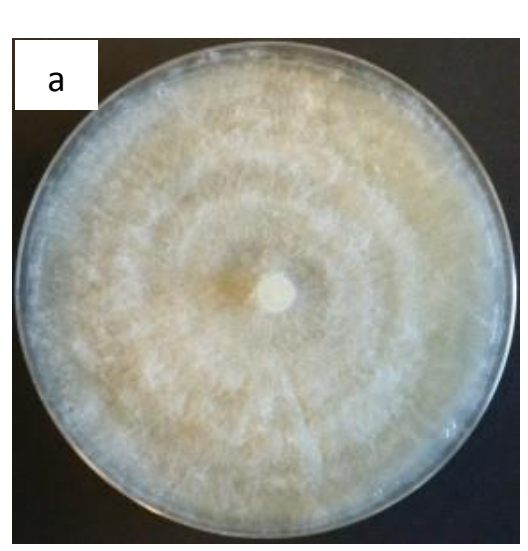

(b)
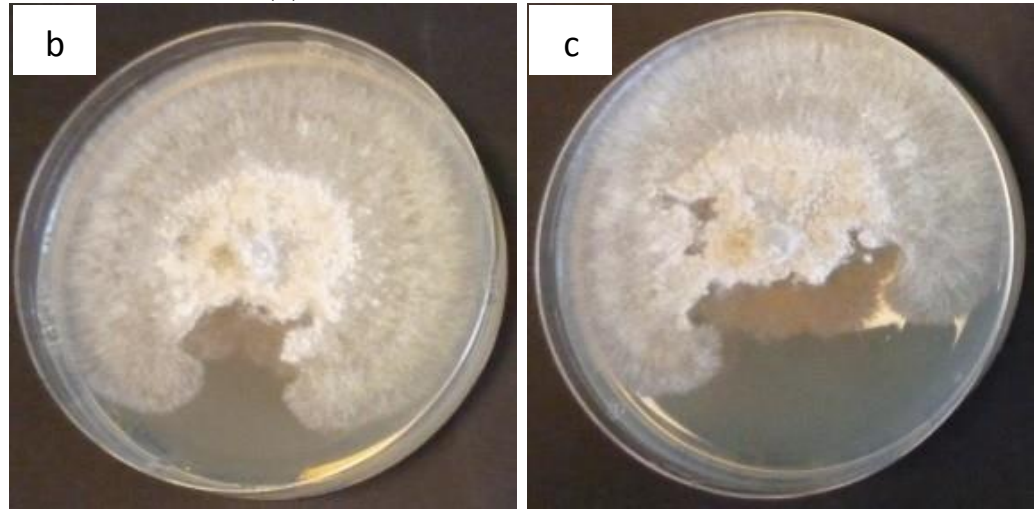

Figure 2. Morphological change toward Rhizoctonia solani colony when exposed to several levels of AgNPs on agar media. (a) AgNPs at $0 \mathrm{mg} \mathrm{L}^{-1}$ (control). (b) AgNPs at $20 \mathrm{mg} \mathrm{L}^{-1}$. (c) AgNPs at $50 \mathrm{mg} \mathrm{L}^{-1}$ [36]

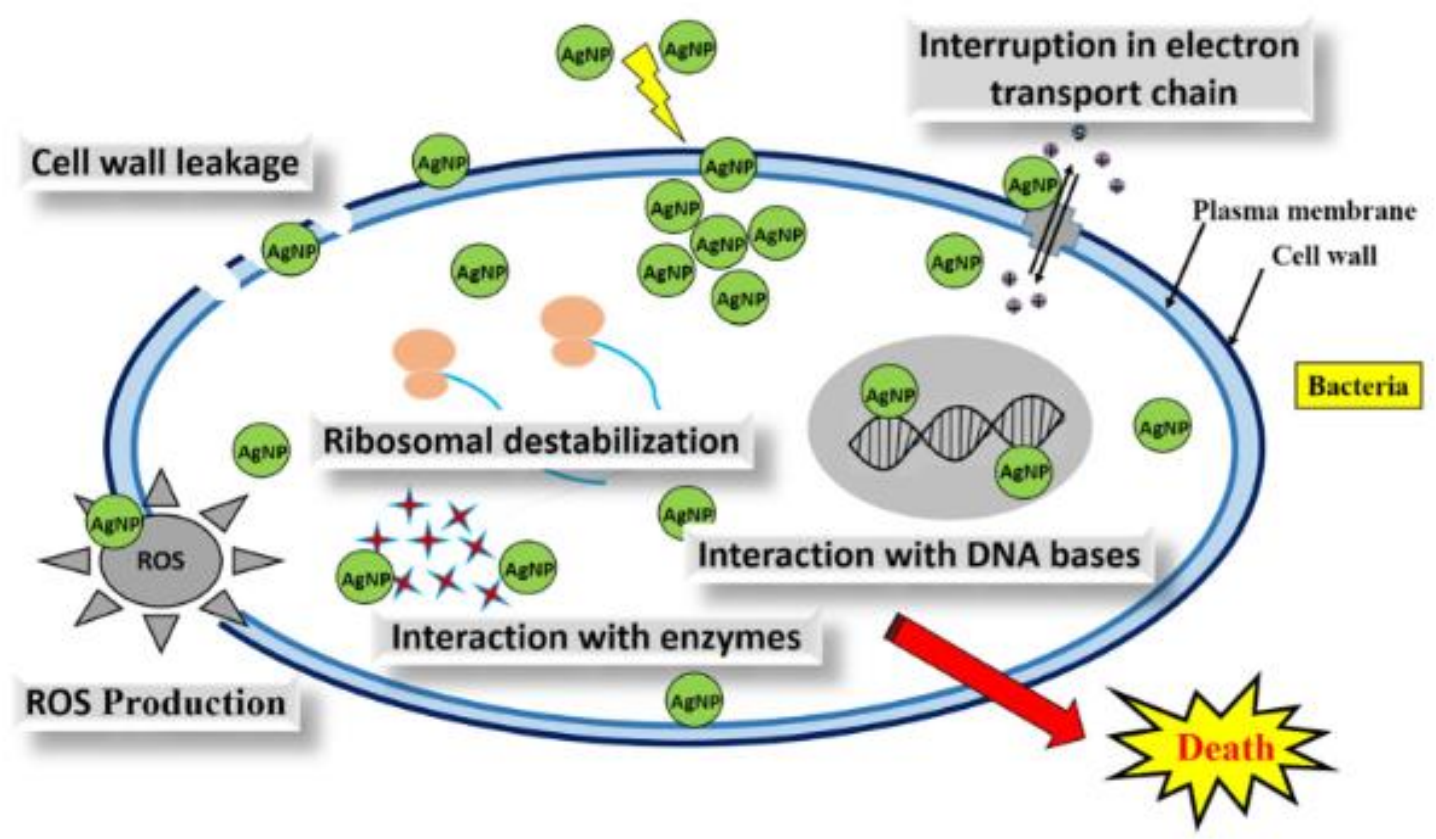

Figure 3. Antibacterial mechanism of silver nanoparticles (AgNPs) [37] 


\section{Heavy Metal Remediation by Microorganism}

Heavy metal remediation by employing microorganisms considered as cost effective, practical, and do not resulting in any secondary pollution [38]. There are two groups of bioremediation by microorganisms, biosorption, and bioaccumulation [39]. Biosorption is a passive adsorption on dead and living biomass while bioaccumulation is an active process on living biomass. Each type of microorganisms has a different role in bioremediation. Bacteria are the most widely used microorganism in bioremediation followed by fungi, yeast and algae [39] as they have the ability to grow either under a controlled condition or extreme environmental condition [40]. Fig. 4 describes the main bioremediation mechanism of bacteria in aquatic environment. Toxic metal from both anthropic and natural action can be the source of metal pollution in water. Researchers proposed that the main bioremediation mechanism of bacteria are bioaccumulation, biosorption, efflux system, as well as extracellular and intracellular enzymatic action [41] [42] [43]. The mechanisms perform by bacteria reduce the toxicity and concentration of heavy metal in the water.

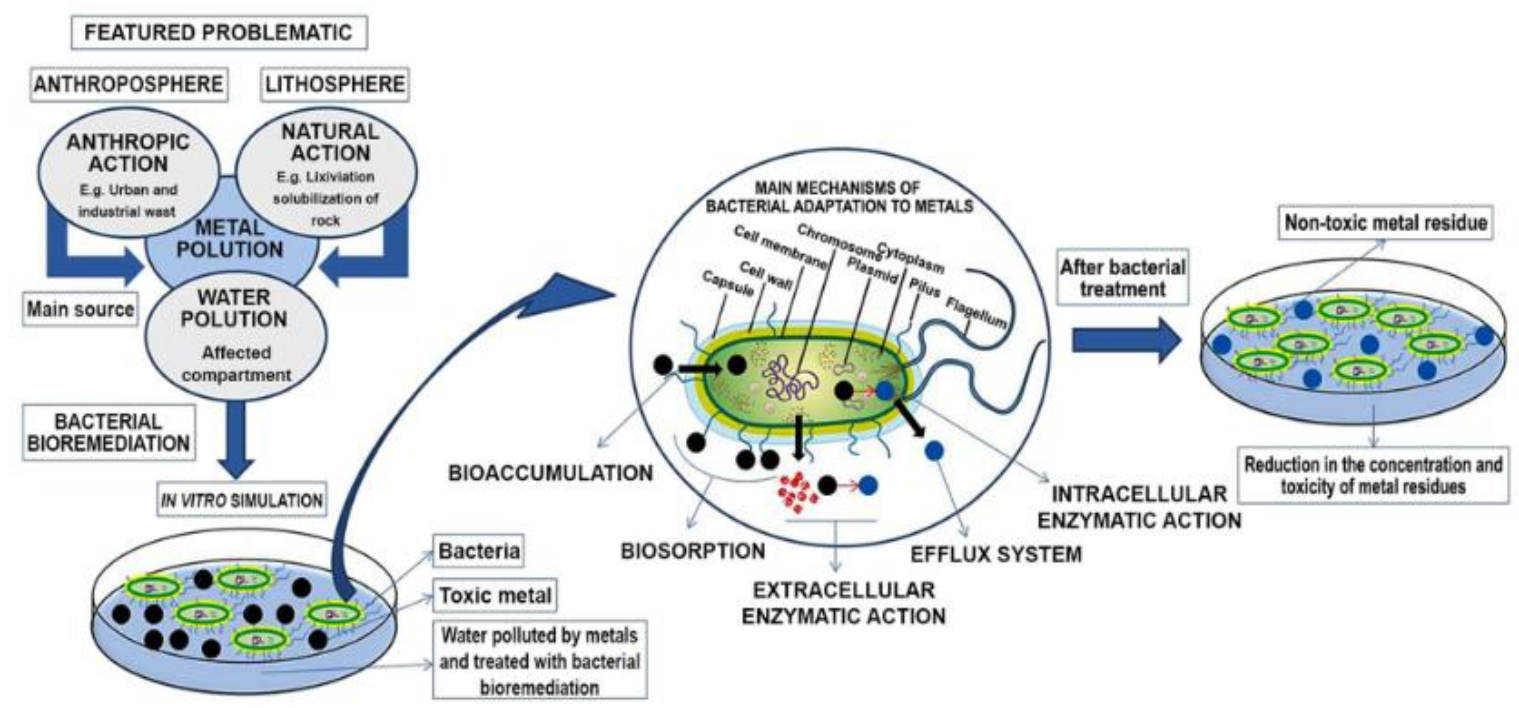

Figure 4. The main bioremediation mechanism of bacteria in aquatic environment [44]

Fungi in particular have been reported as a low cost and an eco-friendly technique to remove heavy metals. [45] Reported that fungi mycelium absorb heavy metals and prevent cell entry. It has been found that some fungal species are related to heavy metal rich area and considered as hyperaccumulators of heavy metal. For example, the genus Trichoderma was referred to as metal tolerant fungus as it was found in soil receiving AgNPs long-term exposure [15]. The finding support Babu et al. [46] that reported that the potential of $T$. virens in bioremediation. They observed that the cell of $T$. virens was thinner and surrounded by extracellular materials without cause physical alteration on the cell surface (Fig. 5). It can be seen from the figure that the heavy metal is accumulated on the hyphae of $T$. virens. Furthermore, the process is resulted in the reduction of vacuole of the fungal. The process of heavy metal accumulation on the cell surface, called bioaccumulation, is depend on the microorganism metabolic activity and the characteristic of the cell surface [39].

According to [47] metal bioremediation activities of Trichoderma species can be classified into four categories. Firstly, the ability of Trichoderma species to accumulate heavy metal (biosorption). Secondly, an active process of metal removal (bioaccumulation). The next strategy is biovolatilization which is generally carried out by intracellular biochemical reactions converting organic and inorganic compounds of metalloids enzymatically. Finally, T. harzianum could be applied as a part of a combination of microbes and plants to remediate pollutants (also known as phytobial-remediation). Heavy metal removal using microorganisms is studied widely as it is less expensive than conventional physico-chemical remediation methods [47]. Furthermore, the natural process of bioremediation is expected to have a minimal impact on the environment when compared to chemical and physical remediation processes. 

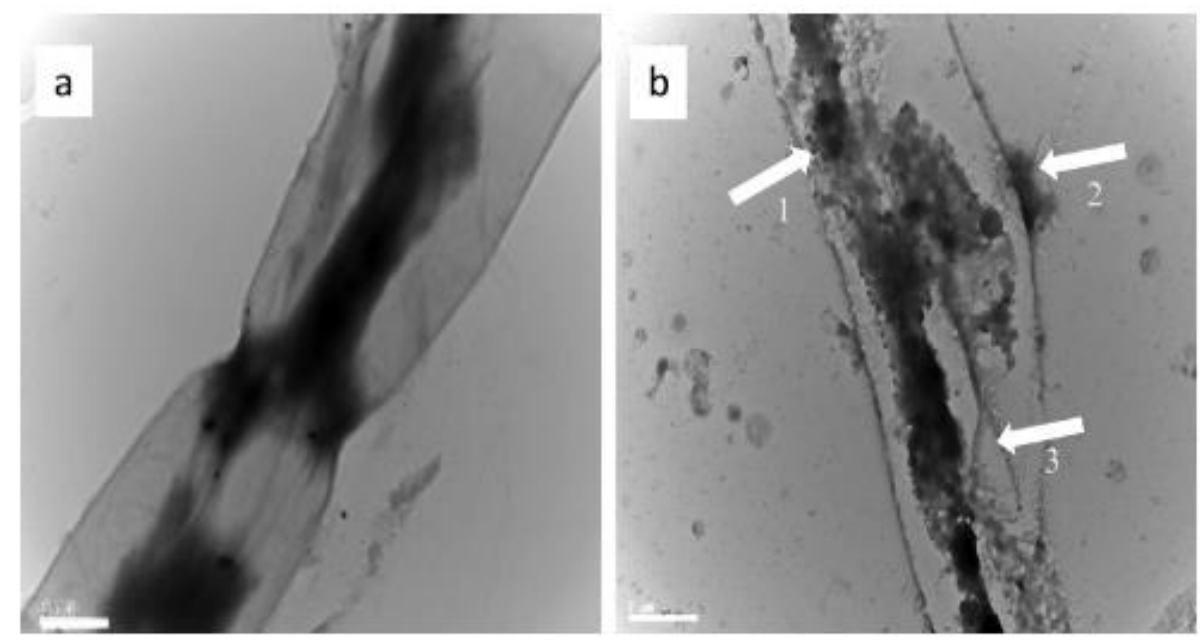

Figure 5. Transmission electron microscopy (TEM) image of Trichoderma virens hyphae (a) hyphal structure of $T$. virens before exposed to heavy metal (b) hyphal structure of $T$. virens after exposed to heavy metal. The hyphae accumulates heavy metal extracellularly (arrow 1and 2) and have a smaller vacuole after exposed to the heavy metal (arrow 3) [46]

Algae also have been reported as an efficient bioaccumulator of heavy metal [40]. It has been reported that microalgae can grow in heavy metal contaminated water that the biomass produced and could be used as efficient absorbent [48]. Absorbency mechanisms are commonly used by algae species to remove nutrients, heavy metal, and other minerals from wastewater [49]. Ref. [50] reported that the green microalga Coccomyxa actinabiotis capable to trap silver (Ag) inside their cells into the cytosol (Fig. 6).

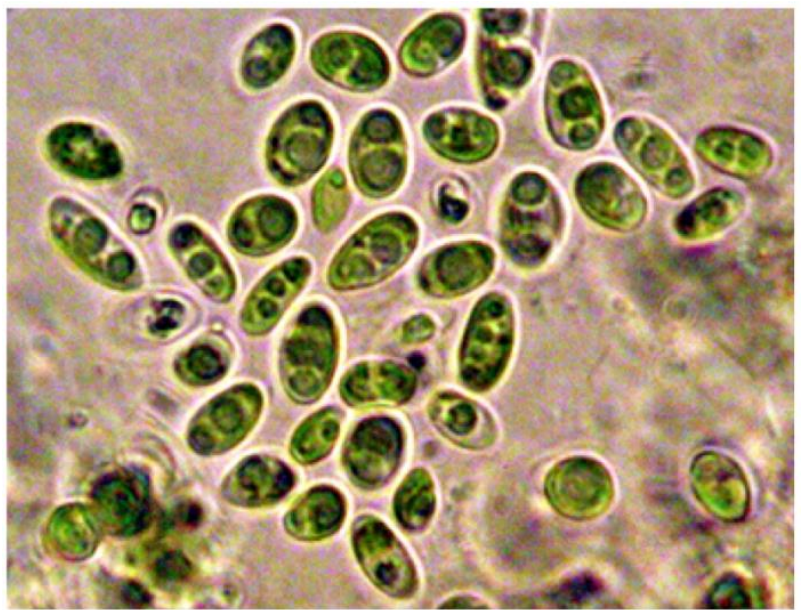

Figure 6. Green microalga Coccomyxa actinabiotis trapped toxic silver inside their cells into the cytosol [50]

Yeasts can be the most abundant source of bioremediation to remove heavy metals as they have the ability to endure a wide range of environmental conditions [38]. In the food industry, Saccharomyces strains are common yeast used to eliminate heavy metals found in wastewater as they are capable of biodetoxification and absorbing certain mycotoxin during the fermentation process [51]. To degrade pollutants in the soil, a mixed microorganism population is required because the metabolism of one species only limited to a number of pollutants [40]. Furthermore, researchers suggested integrating the use of microorganism and plants for bioremediation as they have a symbiont relationship. The combination between rice blast fungus Magnaporthe oryzae and proteobacteria Burkholderia sp. is reported able to reduce $\mathrm{Cd}$ availability in soil [52]. Another study revealed that the efficiency of heavy metal removal is higher with the combination between plant and microbial (58\%) compared to the plant (47\%) and microbial (40\%) only [53].

There is limited study regarding the use of microorganisms to remove AgNPs contamination. The reports on the ability of microorganism to remove heavy metals in general might be a useful reference to study their potential to reduce AgNPs toxicity. Therefore, potential microorganisms as heavy metals bioremediator is presented in Table 1. 
Table 1. Microorganisms known as heavy metal bioremediation agent

\begin{tabular}{|c|c|c|c|}
\hline $\begin{array}{l}\text { Type of } \\
\text { microorganism }\end{array}$ & Species & Heavy metal & Reference \\
\hline \multirow[t]{6}{*}{ Bacteria } & Bacillus cereus, Pseudomonas aureginosa & $\mathrm{Cr}(\mathrm{VI})$ & {$[39][54]$} \\
\hline & B. subtilis & $\mathrm{Cr}(\mathrm{VI}), \mathrm{Cd}, \mathrm{As}$ & {$[55][56]$} \\
\hline & Kocuria flava & $\mathrm{Cu}$ & {$[57]$} \\
\hline & $\begin{array}{l}\text { Escherichia coli, Saccharomyces boulardii, } \\
\text { Enterococcus faecium, Staphylococcus aureus }\end{array}$ & $\mathrm{Cu}$, As & {$[56]$} \\
\hline & Geobacter metallireducens & $\mathrm{U}$ & {$[10]$} \\
\hline & Agaricus bisporus & $\mathrm{Cd}, \mathrm{Zn}$ & {$[58]$} \\
\hline \multirow[t]{4}{*}{ Fungi } & Aspergillus fumigatus & $\mathrm{Pb}$ & [59] \\
\hline & Aspergillus, Mucor, Penicillium and Rhizopus & $\mathrm{Cd}, \mathrm{Cu}, \mathrm{Fe}$ & {$[60]$} \\
\hline & $\begin{array}{l}\text { Aspergillus niger, Trichoderma asperellum, } \\
\text { Penicillum simplicissimum }\end{array}$ & $\mathrm{Cu}, \mathrm{Pb}$ & [61] \\
\hline & T. harzianum, T. asperellum, T. tomentosum & $\mathrm{Cd}$ & {$[62][63]$} \\
\hline \multirow[t]{3}{*}{ Algae } & Hydrodictylon, Oedogonium, Rhizoclonium spp. & $\mathrm{V}$, As & [64] \\
\hline & Spirogyra spp. and Cladophora spp. & $\mathrm{Pb}, \mathrm{Cu}$ & {$[65]$} \\
\hline & Spirogyra spp. and Spirullina spp & $\mathrm{Cr}, \mathrm{Cu}, \mathrm{Fe}, \mathrm{Mn}, \mathrm{Zn}$ & {$[66]$} \\
\hline \multirow[t]{2}{*}{ Yeast } & Saccaromyces cerevisiae & $\mathrm{Cd}$ & [67] \\
\hline & Candida tropicalis, C. glabrata & $\mathrm{Pb}, \mathrm{Co}, \mathrm{Cd}$ & [38] \\
\hline
\end{tabular}

\section{Conclusion}

Literature and studies from various sources indicated that AgNPs potentially harm beneficial microorganisms. However, the technique to remove the particular heavy metal is not well documented. It is necessary to study microorganisms that have been proven capable to remove heavy metal contamination. Bioremediation, in which microorganisms are used to remove heavy metal pollution is a highly promising technique and cost-effective. However, bioremediation is not without limitation. Environment condition is a crucial factor for successful bioremediation. There are also concerns that microorganisms used in bioremediation become more persistent and hazardous. Finally, bioremediation often requires more time as the microorganisms employed need to adapt to the environment as the technique only effective where environmental conditions permit microbial growth and activity.

\section{References}

[1] Zhu K., Shang YY., Sun PZ., Li Z., Li XM., Wei JQ., Wang KL., Wu DH., Cao AY., Zhu HW. 2013. Oil spill clean-up from sea water by carbon nanotube sponges. Front.Mater.Sci: 7(2), 170-176. doi.org/10.1007/s11706-013-0200-1

[2] Murphy M., Ting K., Zhang X., Soo C., Zheng Z. 2015. Current development of silver nanoparticles preparation, investigation, and application in the field of medicine. Journal of nanomaterials. $12 \mathrm{p}$. https://doi.org.10.1155/2015/696918

[3] Singh T., Shukla S., Kumar P., Wahla V., Bajpai VK., Rather IA. 2017. Application nanotechnology in food science: perception and overview. Frontiers in Microbiology, 8, 1501

[4] The Project on Emerging Nanotechnologies. 2013. Silver nanoparticles products. http://www.nanotechproject.org/cpi/browse/nanomaterials/silver-nanoparticle/

[5] Limpiteeprakan P., Babel S., Lohwacharin J., Takizawa S. 2016. Release of silver nanoparticles from fabrics during the course of sequential washing. Environ Sci Pollut Res Int. 23(22):22810-22818. doi: 10.1007/s11356-016-7486-3

[6] Schlich K., Klawonn T., Terytze K., Hund-Rinke K. 2013. Hazard assessment of a silver nanoparticle in soil applied via sewage sludge. Environmental Sciences Europe 25:17

[7] Kim SW., Jung JH., Lamsal K., Kim YS., Min JS., Lee YS. 2012. Antifungal effects of silver nanoparticles (AgNPs) against various plant pathogenic fungi. Mycobiology. 40(1): 53-58

[8] Siripattanakul-Ratpukdi S., Fürhacker M. 2014. Review: Issues of silver nanoparticles in engineered environmental treatment systems. Water Air Soil Pollut 225: 1939

[9] Hänsch M., Emmerling C. 2010. Effects of silver nanoparticles on the microbiota and enzyme activity in soil. J. Plant Nutr. Soil Sci., 173: 554-558

[10] Kumar A., Bisht BS., Joshi VD., Dhewa T. 2011. Review on bioremediation of polluted environment: a management tool. International Journal of Environmental Sciences; 1 (6) 1079-1093.

[11] Calder AJ., Dimkpa CO., McLean JE., Britt DW., Johnson W., Anderson AJ. 2012. Soil components mitigate the antimicrobial effects of silver nanoparticles towards a beneficial soil bacterium, Pseudomonas chlororaphis O6. Sci Total Environ 429:215222 
[12] Sweet MJ., Singleton I. 2015. Soil contamination with silver nanoparticles reduces Bishop pine growth and ectomycorrhizal diversity on pine roots. J Nanopart Res. 17: 448

[13] Anjum, N.A., Gill, S.S., Duarte, A,C., Pereira, E., Ahmad, I. 2013. Silver nanoparticles in soil-plant systems J. Nanopart Res., 15:1896

[14] Grün AL., Manz W., Kohl Y.L., Meier F., Straskraba S., Jost C., Drexel R., Emmerling C. 2019. Impact of silver nanoparticles (AgNP) on soil microbial community depending on functionalization, concentration, exposure time, and soil texture. Environ Sci Eur 31, 15. https://doi.org/10.1186/s12302-019-0196-y

[15] Oktarina H., Singleton I. 2020a. Can nano-silver products endanger beneficial soil fungi? IOP Conf. Series: Earth and Environmental Science 425, 012070 doi:10.1088/1755-1315/425/1/012070

[16] Oktarina H., Singleton I. 2020b. Soil fungal community responses to the silver nanoparticles contamination as assessed by illumina next generation sequencing (NGS). Jurnal Rekayasa Kimia dan Lingkungan (Journal of Chemical Engineering and Environment) 15(2), 99-103

[17] Cornelis G., Thomas CD., McLaughlin MJ., Kirby JK., Beak DG., Chittleborough D. 2012. Retention and dissolution of engineered silver nanoparticles in natural soils. Soil Sci. Soc. Am. J. 76:891-902

[18] Coutris C., Hertel-Aas T., Lapied E., Joner EJ., Oughton DH .2012. Bioavailability of cobalt and silver nanoparticles to the earthworm Eisenia fetida. Nanotoxicology 6: 186-195

[19] Levard C., Hotze EM., Lowry GV., Brown GE. 2012. Environmental transformations of silver nanoparticles: Impact on Stability and Toxicity. Environ. Sci. Technol 46: 6900-6914

[20] Tourinho PS., Van Gestel CA., Lofts S., Svendsen C., Soares AM., Loureiro S. 2012. Metal-based nanoparticles in soil: fate, behavior, and effects on soil invertebrates. Environ. Toxicol. Chem. 31: 1679-1692

[21] Benoit R., Wilkinson KJ., Sauvé S. 2013. Partitioning of silver and chemical speciation of free Ag in soils amended with nanoparticles. Chem Cent J 7:75

[22] Sagee O., Dror I., Berkowitz B. 2012. Transport of silver nanoparticles (AgNPs) in soil. Chemosphere. 88(5):670-675

[23] Lowry GV., Espinasse BP., Badireddy AR., Richardson CJ., Reinsch BC., Bryant LD., Bone AJ., Deonarine A., Chae S., Therezien M., Colman BP., Hsu-Kim H., Bernhardt ES., Matson CW., Wiesner MR. 2012. Long-term transformation and fate of manufactured ag nanoparticles in a simulated large scale freshwater emergent wetland. Environ Sci Technol. 3;46(13):7027-36

[24] Mirzajani F., Ghassempour A., Aliahmadi A., Esmaeili MA. 2011. Antibacterial effect of silver nanoparticles on Traphylococcus aureus. Research in Microbiology, 162(5): 542-549

[25] El Badawy AM., Silva RG., Morris B., Scheckel KG., Suidan MT., Tolaymat TM. 2011. Surface Charge-Dependent Toxicity of Silver Nanoparticles. Environ. Sci. Technol. 45, 283-287

[26] Sharma S., Tiwari S., Hasan A., Saxena V., Pandey LM.2018. Recent advances in conventional and contemporary methods for remediation of heavy metal-contaminated soils. 3 Biotech 8, 216. https://doi.org/10.1007/s13205-018-1237-8

[27] Vishwakarma GS., Bhattacharjee G., Gohil N., Singh V. 2020. Current status, challenges and future of bioremediation. Bioremediation of Pollutants, 403-415. doi:10.1016/b978-0-12-819025-8.00020$\mathrm{x}$

[28] Toor MD., Adnan M. 2020. Role of Soil Microbes in Agriculture: A Review. Open access Journal of Biogeneric and Research. doi:10.46718/JBGSR.2020.04.000091

[29] Kumar N., Palmer GR., Shah V., Walker VK. 2014. Thee effect of silver nanoparticles on seasonal change in Arctic Tundra bacterial and fungal assemblages. PLoS One 9(6): e99953

[30] Yang Y., Quensen J., Mathieu J., Wang Q., Wang J., Lia M., Tiedje JM., Alvarez PJJ. 2014. Pyrosequencing reveals higher impact of silver nanoparticles than $\mathrm{Ag}+$ on the microbial community structure of activated sludge. Water research 48: 317-325

[31] Das P., Xenopoulos MA., Williams CJ., Hoque MdE., Metcalfe CD .2012. Effects of silver nanoparticles on bacterial activity in natural waters. Enviromental Toxicology and Chemistry 31(1): $122-130$

[32] Derbalah AS., Elkot GA., Hamza AM. 2012. Laboratory evaluation of botanical extracts, microbial culture filtrates and silver nanoparticles against Botrytis cinerea. Annals of Microbiology 62 (3):1331-133

[33] Xiang S., Ma X., Shi H., Ma T., Tian C., Chen Y., Chen H., Chen X., Luo K., Cai L., Wang D., Xue Y., Huang J., Sun X. 2019. A green synthesis of alginate-coated silver nano-particle shows high antifungal activity by enhancing its cell membrane penetrating ability. ACS Applied Bio Materials, (), acsabm.9b00590-, doi:10.1021/acsabm.9b00590 
[34] Yu Z., Wang W., Dhital R., Kong F., Lin M., Mustapha A. 2019. Antimicrobial effect and toxicity of cellulose nanofibril/silver nanoparticles nanocomposites prepared by an ultraviolet irradiation $\begin{array}{lllll}\text { method. Calloids and } & \text { Surface B: Biointerfaces, 180: } 220 \text {. }\end{array}$ https://doi.org/10.1016/j.colsurfb.2019.04.054

[35] Liao S., Zhang Y., Pan X., Zhu F., Jian C., Liu Q., Cheng Z., Dai G., Wu G., Wang L., Chen L. 2019. Antibacterial activity and mechanism of silver nanoparticles against multidrug-resistant Pseudomonas aureginosa. International Journal of Nanomedicine: 14, 1469-1487. doi:10.2147/IJN.S191340

[36] Oktarina H., Woodhall J., Singleton I. 2021. The potential of silver nanoparticles to control Rhizoctonia solani (AG3-PT) growth in vitro. Jurnal Natural: 21 (1) doi 10.24815/jn.v2lil.17555

[37] Patil MP., Kim G. 2016. Eco-friendly approach for nanoparticles synthesis and mechanism behind antibacterial activity of silver and anticancer activity of gold nanoparticles. Appl Microbiol Biotechnol. doi 10.1007/s00253-016-8012-8

[38] Abbas BA., Badr, SQ. 2015. Bioremediation of some types of heavy metals by Candida spp. IJETR 3, 2454-4698.

[39] Coelho LM., Rezende HC., Coelho LM., deSousa PA., Melo DF., Coelho NM., 2015. Bioremediation of polluted waters using microorganisms. In: Shiomi, N. (Ed.), Advances in Bioremediation of Wastewater and Polluted Soil. InTech, Shanghai, China.

[40] Pal, AK., Singh J., Soni R., Tripathi P., Kamle M., Tripathi V., Kumar, P. 2020. The role of microorganism in bioremediation for sustainable environment management. Bioremediation of Pollutants, 227-249. doi:10.1016/b978-0-12-819025-8.00010-7

[41] Kim K., Yang E., Vu GP., Gong H., Su J., Liu F., Lu S. 2010. Mass spectrometry-based quantitative proteomic analysis of Salmonella enterica serovar Enteritidis protein expression upon exposure to hydrogen peroxide. BMC Microbiol 8:10-166

[42] Abdelatey LM., Khalil WKB., Ali TA., Mahrous KF. 2011. Heavy metal resistance and gene expression analysis of metal resistance genes in gram-positive and gram-negative bacteria present in egyptian soils. J Appl Sci Environ Sanit 6(2):201-211

[43] Vargas-García MC., López MJ., Suárez-Estrella F., Moreno J. 2012. Compost as a source of microbial isolates for the bioremediation of heavy metals: in vitro selection. Sci Total Environ 431:62-67

[44] de Alencar FLS., Navoni JA., do Amaral VZ. 2017. The use of bacterial bioremediation of metals in aquatic environments in the twenty-first century: a systematic review. Environmental Scince and Pollution Research. (),- doi:10.1007/s11356-017-9129-8

[45] Deng XH., Chai L.Y., Yang ZH., Tang CJ., Tong HX., Yuan PF., 2012. Bioleaching of heavy metals from a contaminated soil using indigenous Penicillium chrysogenum strain F1. J. Hazard. Mater. 233, $25 \mathrm{e} 32$.

[46] Babu AG., Shim J., Bang K., Shea PJ., Oh B. 2014. Trichoderma virens PDR-28: A heavy metaltolerant and plant growth-promoting fungus for remedation and bioenergy crop production on mine tailing soil. Journal of Environmental Management, 132, 129-134

[47] Tripathi P., Singh PC., Mishra A., Chauhan PS., Dwivedi S., Bais RT., Tripathi RD. 2013. Trichoderma: a potential bioremediator for environmental clean up. Clean Techn Environ Policy 15:541-550

[48] Sreekumar N., Udayan A., Srinivasan S. 2020. 11 - Algae bioremediation of heavy metals. Shah MP. (Ed.) Removal of toxic pollutant through microbiological and tertiary treatment. Elsevier. P 279-307. https://doi.org/10.1016/B978-0-12-821014-7.00011-3

[49] Bwapwa JK., Jaiyeola AT., Chetty R. 2017. Bioremediation of acid mine drainage using algae strains: A review. South African Journal of Chemical Engineering, 24: 62-70. https://doi.org/10.1016/j.sajce.2017.06.005

[50] Leonardo T., Farhi E., Pouget S., Motellier S., Boisson A., Banerjee D., Rébeillé F., den Auwer C., Rivasseau C. 2016. Silver accumulation in the green microalga Coccomyxa actinabiotis: Toxicity, in situ speciation, and localization investigated using synchrotron XAS, XRD, and TEM. Environ. Sci. Technol. 2016, 50, 1, 359-367. https://doi.org/10.1021/acs.est.5b03306

[51] García-Béjar, B., Arévalo-Villena, M., Guisantes-Batan, E.,Rodríguez-Flores J., Briones, A. 2020. Study of the bioremediatory capacity of wild yeasts. Sci Rep 10,11265. https://doi.org/10.1038/s41598-020-68154-4

[52] Dourado M., Martins P., Quecine M., Piotto F., Souza L., Franco M., Tezotto T., Azevedo R. 2013. Burkholderia sp. SCMS54 reduces cadmium toxicity and promotes growth in tomato. Ann Appl Biol163(3):494-507 
[53] Ibuot A., Dean AP., McIntosh OA., Pittman JK. 2017. Metal bioremediation by CrMTP4 overexpressing Chlamydomonas reinhardtii in comparison to natural wastewater-tolerant microalgae strains. Algal Res 24:89-96

[54] Thatoi H., Das S., Mishra J., Rath BP., Das N. 2014. Bacterial chromate reductase, a potential enzyme for bioremediation of hexavalent chromium: a review. Journal of Environmental Management; 146 383-399

[55] Balamurugan D., Udayasooriyan C., Kamaladevi B., 2014. Chromium (VI) reduction by Pseudomonas putida and Bacillus subtilis isolated from contaminated soils. Int. J. Environ. Sci. 5, 522.

[56] Bhakta JN., Munekage Y., Ohnishi K., Jana BB., Balcazar JL. 2014. Isolation and characterization of cadmium and arsenic-absorbing bacteria for bioremediation. Water, air, and soil pollution, 225, 21502159

[57] Achal V., Pan X., Zhang D., Fu Q. 2012. Bioremediation of Pb-contaminated soil based on microbially induced calcite precipitation. J. Microbiol. Biotechnol. 22, 244-247

[58] Nagy B., Mânzatu C., Maicaneanu A., Indolean C., Lucian BT., Majdik C. 2014. Linear and nonlinear regression analysis for heavy metals removal using Agaricus bisporus macrofungus. Arabian Journal of Chemistry 014; http://dx.doi.org/10.1016/j.arabjc.

[59] Ramasamy RK., Congeevaram S., Thamaraiselvi K. 2011. Evaluation of isolated fungal strain from ewaste recycling facility for effective sorption of toxic heavy metal $\mathrm{Pb}$ (II) ions and fungal protein molecular characterization-a Mycoremediation approach. Asian Journal of Experimental Biological Sciences; 2(2) 342-347

[60] Fulekar MH., Sharma J., Tendulkar A. 2012. Bioremediation of heavy metals using biostimulation in laboratory bioreactor. Environmental Monitoring and Assessment; 184(12): 7299-7307.

[61] Iskandar NL., Zainudin NA., Tan SG. 2011. Tolerance and biosorption of copper $(\mathrm{Cu})$ and lead $(\mathrm{Pb})$ by filamentous fungi isolated from a freshwater ecosystem. J Environ Sci (China) 23: 824-830

[62] Mohsenzadeh F., Shahrokhi F. 2014. Biological removing of Cadmium from contaminated media by fungal biomass of Trichoderma species. J Environ Health Sci Eng. 12: 102

[63] Lima AF., Moura GF., Lima MAB., Souza PM., Silva CAA., Takaki GMC., Nascimento AE. 2011. Role of the Morphology and Polyphosphate in Trichoderma harzianum Related to Cadmium Removal. Molecules 16: 2486-2500

[64] Saunders RJ., Paul NA., Hu Y., de Nys R. 2012. Sustainable sources of biomass for bioremediation of heavy metals in wastewater derived from coal-fired power generation. PLoS One. ; 7(5): e36470

[65] Lee YC., Chang SP. 2011. The biosorption of heavy metals from aqueous solution by Spirogyra and Cladophora filamentous macroalgae. Bioresource Technology; 102 (9) 5297-5304

[66] Mane PC., Bhosle AB. 2012. Bioremoval of some metals by living Algae spirogyra sp. and Spirullina sp. from aqueous solution. International Journal of Environmental Research; 6(2) 571-576

[67] Massoud R., Hadiani MR., Hamzehlou P., Khosravi-Darani K. 2019. Bioremediation of heavy metals in food industry: Application of Saccaromyces cerevisiae. Electronic Journal of Biology: 37: 56-60. https://doi.org/10.1016/j.ejbt.2018.11.003 